\title{
DIRECT VULCANIZATION ADHESION OF NICKEL PLATINGS TO NBR COMPOUNDED WITH SOFTENER USING TRIAZINE TRITHIOL MONOSODIUM SALT
}

Hidetoshi HIRAHARA, Kunio MORI, Yoshiyuki OISHI and Toru AIDA (Department of Applied Chemistry and Mólecular Science, Faculty of Engineering Iwate University, 3-5 Ueda 4 Morioka, Iwate 020-8551), Yaeko SASAKI, Shingo OMURA (TOADENKA Co. Ltd, Iwahana, Shibutami, Iwategun, Iwate, 020-4132)

Direct vulcanization adhesion of nickel platings to NBR compounded with the softener using 1 , 3, 5-triazine-2, 4,6-trithiol monosodium salt (TTN) has been investigated. The softener was using aromatic hydrocarbon formaldehyde resin (AHF) and di-octyl-phthalate (DOP). It was found that TTN accelerated vulcanization reactions of NBR compounded with the softener. The tensile strength of NBR compounded with more than 50phr AHF was showed constant value of $7.5 \mathrm{MPa}$, and the elongation at break decreased with increasing the amount of AHF. On the other hand, the tensile strength of NBR/DOP decreased with increasing the amount of DOP.

The peel strength of adhesion was influenced by the amount of TTN, curing temperature, curing time and the amount of softener. The adhesion interface of nickel platings to NBR/AHF left standing for more than 48 hours in air became the cohesive failure. The concentration of sulfur in the interfacial layer of nickel plating NBR compounded with the softener were observed to increase from EDS analysis. The above results suggest that TTN works as a binder which bonds between nickel platings and NBR compounded with the softener.

(Received on September 17, 1997)

Key Word : direct valcanization adhesion, nickel platings, NBR, softener, EDS, 1, 3, 5-triazine-2, 4, 6-trithiol, aromatic hydrocarbon formaldehyde resin, di-octyl-phthalate

\section{1. 緒言}

近年, 電子電気機器, 自動車や情報通信機器な どに用いられる高速で往復運動や回転する部品, そしてスピーカ振動板等の音響部品では, 振動が 長く残ったり，共振が発生しないようにするため
に防振・制振そして防音技術が非常に重要となっ てきている。このような部品には弾性率が高く振 動減衰性の大きい材料が要求される。一般に単一 材料では弾性率の高い材料は振動減衰性が小さ く, また振動減衰性の大きい材料は弾性率が低い という二律背反性にある.ゴム材料の振動减衰性 
<smiles>[R]c1ccc(COCc2c([R2])ccc([R])c2C)c(C)c1</smiles>

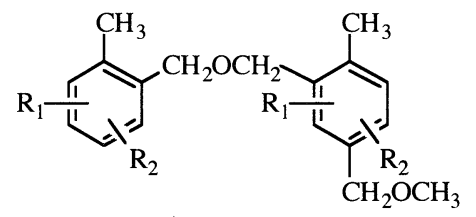

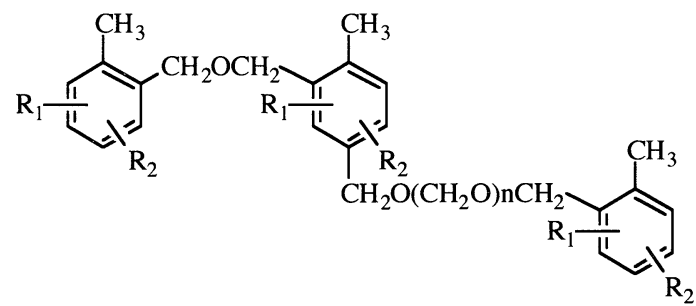

Fig. 1 Chemical structures of aromatic hydrocarbon formaldehyde resin

向上の手段1)としては，(1)可塑性付与剂を添加す る方法, (2)添加剂を混合して IPN (相互侵入高分 子網目)を形成させる方法 ${ }^{2)},(3)$ ゴム分子鎖の構 造を変性する方法などが考えられる31,4).これら 防振・制振材料として使用されるゴムは，金属と 複合化することによって使用されている，金属と ゴムの接着には接着剂が利用されているが，制振 性・防振性を発現させるためにゴムに配合される 軟化剂が，接着剂と相溶しないために接着不良を 起こす原因となる場合もある。一方，我々はアク リロニトリルーブタジエンゴム (NBR)にトリアジ ントリチオールモノナトリウム塩を添加すること によるニッケルめっきとの直接加硫接着 ${ }^{5)}$, また フッ素ゴムにトリアジントリチオールアンモニウ
ム塩を添加することによるニッケルめっきとの直 接架橋接着(6)を可能とした。 そして，トリアジン トリチオールがニッケルとゴムとのバインダーと して作用し，ゴムが破断するほど強固な接着物が 得られることを報告した。

本報では，制振性・防振性の期待できる軟化剂 を配合したNBR とニッケルめっきの直接加硫接 着を, トリアジントリチオールをバインダーとし て検討し, 直接加硫接着に与える軟化剂の影響に ついて検討した。

\section{2. 実}

験

\section{1 試料と材料}

ニッケルめっき板の基材として冷延鋼板 $(0.25 \times 30 \times 60 \mathrm{~mm}, \mathrm{SPCC})$ を用いた. 冷延鋼板 はアルカリ脱脂液(荏原ユージライト侏製 $\mathrm{OP}$ 144) に $60^{\circ} \mathrm{C}$ で 1 分間脱脂後, 金属活性液(荏原工 ージライト(侏)製 OV-345)に常温で 30 秒間浸せき して前処理を行った. 無電解ニッケルめっきは日 本カニゼン怢製の無電解ニッケルめっき液を使用 して $90 \sim 92^{\circ} \mathrm{C} て ゙$ 所定時間浸せきしてめっき厚 $0.2 \sim 5 \mu \mathrm{m}$ に調整し ${ }^{7)}, 20^{\circ} \mathrm{C}$ ，湿度 $60 \%$ の恒温 室に所定時間放置したものを使用した。NBR と して Nipol-1042(日本ゼオン(猅)製)を使用した。 軟化剂として芳香族炭化水素ホルムアルデヒド樹 脂 (以下 $\mathrm{AHF}$ 樹脂と略す。商品名ゼネライト 4050，ゼネラル石油(䎺)を使用した。AHF 樹脂 の構造と性質を Fig. 1 と Table 1 に示す ${ }^{8)}$. ま た，ジオクチルフタレート (DOP) は市販品を使 用した。カーボンプラックは旭カーボン猘製旭井 50 (SRF，ASTM No. N-770)を使用した。加硫 促進剂としてテトラメチルチウラムモノスルフィ ド (TMTM) は市販品をそのまま使用した。硫黄 $(\mathrm{S})$ ，ステアリン酸 $(\mathrm{St})$ と亜鉛華 $(\mathrm{ZnO})$ は市販品 をそのまま使用した。 $1 ， 3,5$-トリアジンー 2 ，

Table 1 Properties of AHF resin or DOP

\begin{tabular}{lcc}
\hline \multicolumn{1}{c}{ Properties } & AHF resin & DOP \\
\hline Appearance & Light-Amber & Liquid \\
& Viscous Liquid & \\
Viscosity at $25^{\circ} \mathrm{C}(\mathrm{Pa} \cdot \mathrm{s})$ & 4.39 & 0.0 \\
Number-Average Molecular Weight & 427 & \\
Weight-Average Molecular Weight & 700 & \\
Molecular Weight & & 390 \\
Oxygen Content $(\mathrm{wt} \%)$ & 8.1 & 16.0 \\
\hline
\end{tabular}




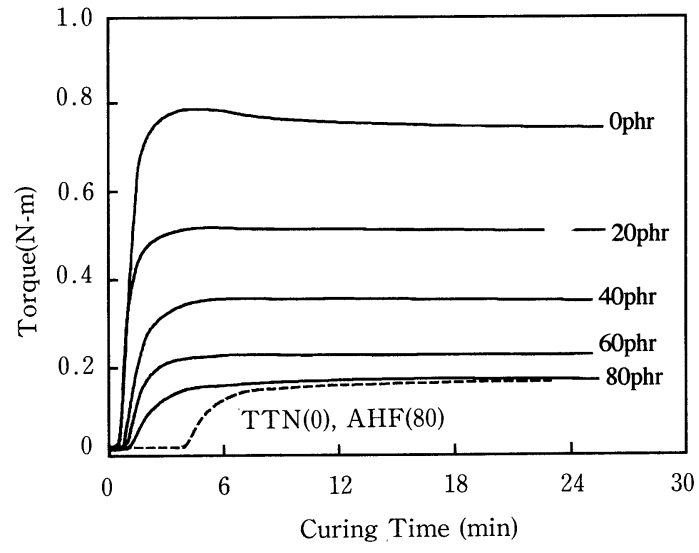

Fig. 2 Effect of the amount of AHF resin on the curing curve of NBR.

*NBR compound (phr); Nipol-1042(100), SRFblack (40), St (1), ZnO(5), TMTM(0.5), AHF resin(ver.), S (1. 5), $\operatorname{TTN}(1.5)$

Press condition ; $190^{\circ} \mathrm{C}$

4, 6-トリチオール・モノナトリウム塩(TTN) は 市販品をメ夕ノールで再結晶して使用した。

\section{2 配合, 混練と架橋接着}

NBR $100 \mathrm{phr}$, SRF $40 \mathrm{phr}, \mathrm{AHF}$ 樹脂又は DOPを混練りしてマスターバッチゴムを調製し た. 加硫促進剂, 硫黄そしてTTN は実験用小型 ロールで配合, 混練りし厚さ約 $3 \mathrm{~mm}$ の未加硫 ゴムシートを調製した。直接加硫接着はニッケル めっき板と TTN 配合未加硫ゴムを接触させて金 型に入れ，所定温度で 30 分間ホットプレスして 行い, 加硫ゴムの厚さは約 $2.5 \mathrm{~mm}$ に調製して 接着物を得た. EDS 分析用接着物の断面はニッ ケルめっき筞を TTN 配合未加硫ゴムで挟み, 直 接加硫接着後, 液体窒素によって凍結破壊して得 た.

\section{3 試験および測定}

軟化剂配合 NBR の加硫特性は(侏)東洋精機製作 所製オシレーティングディスクレオメーターを用 いて測定した。機械的特性 (引張強度； $\mathrm{T}_{\mathrm{B}}$ $[\mathrm{MPa}]$, 破断伸び; $\left.\mathrm{E}_{\mathrm{B}}[\%]\right)$ は NBR 加硫シー トをJIS 3 号ダンベルカッター(ダンベル(株製, SDL-200，865)で打ち抜いた試料を引張試験機 P-100 (株島津製作所製)を用いて引張速度 200 $\mathrm{mm} / \mathrm{min}$. で測定した. 接着物のはく離強さは接 着試料を 24 時間放置後ゴム側に幅 $1 \mathrm{~cm}$ の切込 みを入れ，引張試験機 $\mathrm{P}-100$ を用い, $\mathrm{T}$ 字形は

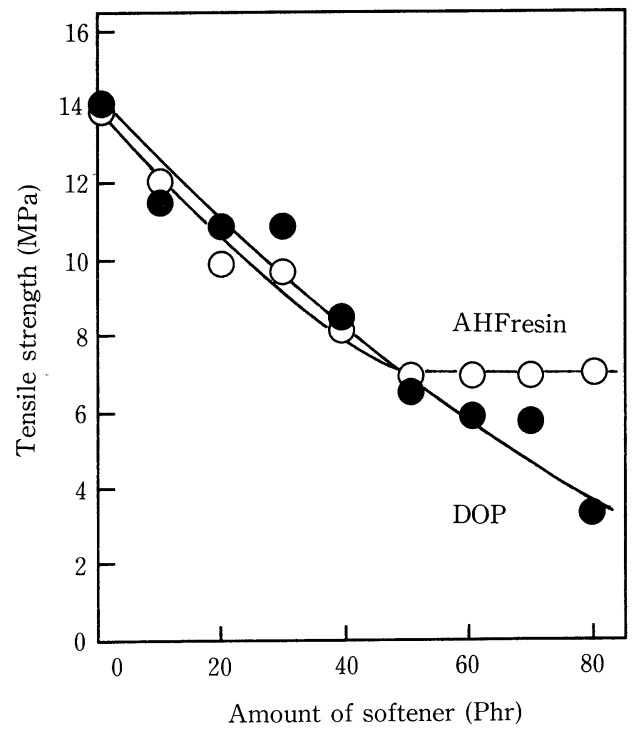

Fig. 3 Effect of the amout of softener on the tensile strength of NBR.

*NBR compound (phr) ; Nipol-1042(100), SRFblack (40), $\mathrm{St}(1), \mathrm{ZnO}(5), \operatorname{TMTM}(0.5)$, AHFresin or DOP (ver.), S(1.5), TTN (1.5)

Press condition; $190^{\circ} \mathrm{C}$ for $30 \mathrm{~min}$

く離試験 (JIS K 6301-1975, 引張速度 ; 50 mm/ min.) で測定した. 接着物断面は日本電子(侏製走 査型電子顕微鏡 JSM-T $330 \mathrm{~A}$ を用いて観察し た。接着物界面と断面の元素分析は日本電子(侏製 エネルギー分散型 $\mathrm{X}$ 線マイクロアナライザー JED-2000(EDS)によって行った。

\section{3. 結 果と考察}

\section{1 軟化剂配合 NBR の物性}

防振，制振等に利用される多くのゴムは軟化剂 等を配合することによって振動減衰性向上の手段 としている．また，我々はゴム材料と金属のよう な異種材料の接着において強い接着力を得るため に, 界面にトリアジントリチオールによって一次 結合を生成させることが接着には不可欠であると 考えた ${ }^{5), 99}$. そこで，軟化剂配合 NBRの加硫ゴ ム物性に及ぼす接着のバインダーとなる TTNの 影響について検討した. Fig. 2 は加硫温度 $190^{\circ} \mathrm{C}$ での AHF 樹脂配合 NBR の加硫曲線に及ぼす $\mathrm{AHF}$ 樹脂配合量の影響を示している. AHF 樹 


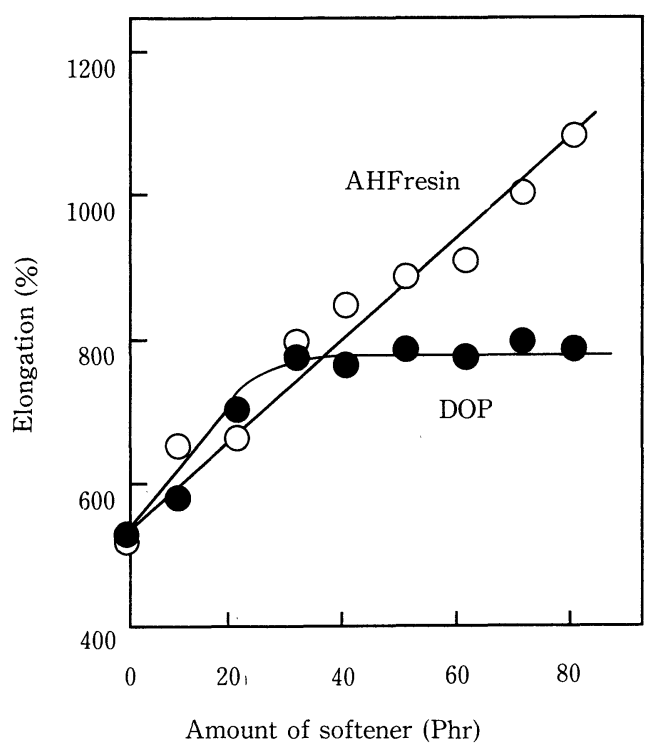

Fig. 4 Effect of the amount of softener on the elongation of NBR.

*NBR compound (phr); Nipol-1042(100), SRFblack (40), $\mathrm{St}(1), \mathrm{ZnO}(5), \operatorname{TMTM}(0.5)$, AHF resin or DOP (ver.), S(1.5), TTN (1.5)

Press condition ; $190^{\circ} \mathrm{C}$ for $30 \mathrm{~min}$

脂量が増加するとともにトルクが低下した. TTN を配合することによって誘導期が短縮し， TTN が加硫促進剂として作用することが明らか となった. Fig. 3 および 4 は $\mathrm{T}_{\mathrm{B}}$ と $\mathrm{E}_{\mathrm{B}}$ に及ぼす $\mathrm{AHF}$ 樹脂または DOP 配合量の影響を示してい る. $40 \mathrm{phr}$ まで軟化剂量を増加させた場合 $\mathrm{AHF}$ 樹脂配合 NBR と DOP 配合 NBR の $T_{\mathrm{B}}$ および $\mathrm{E}_{\mathrm{B}}$ はほとんど同様の值を示した。 $\mathrm{AHF}$ 樹脂を $50 \mathrm{phr}$ 以上配合した場合, $\mathrm{T}_{\mathrm{B}}$ は $7.5 \mathrm{MPa}$ で一 定の值を示し， $\mathrm{E}_{\mathrm{B}}$ は $\mathrm{AHF}$ 樹脂配合量の増加と ともに増加する傾向にあった。一方 DOPを 40 $\mathrm{phr}$ 以上配合した場合， $\mathrm{E}_{\mathrm{B}}$ は $780 \%$ で一定の值 を示すが, $\mathrm{T}_{\mathrm{B}}$ は $\mathrm{DOP}$ 配合量とともに減少した。 このように AHF 樹脂配合は DOP 配合と異なる 挙動を示した. Fig. 5 は AHF 樹脂配合 NBRの $\mathrm{T}_{\mathrm{B}}$ と $\mathrm{E}_{\mathrm{B}}$ に及ぼす TTN 配合量の影響を示して いる. TTN 配合量が増加すると $\mathrm{T}_{\mathrm{B}}$ は減少し, $\mathrm{E}_{\mathrm{B}}$ はほとんど一定の值を示した。これはTTN を配合した AHF 樹脂配合 NBRの最大トルク值 が未配合より上昇することから，過加硫の状態に なると考えられる。またトリアジントリチオール

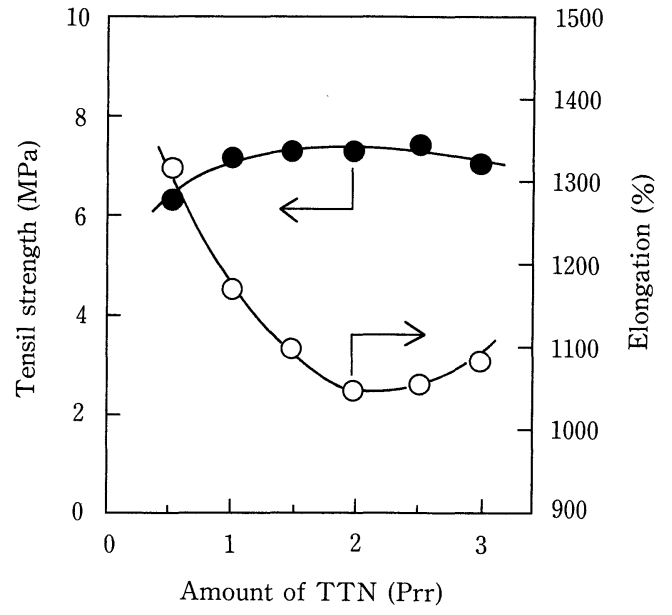

Fig. 5 Effect of the amount of TTN on the tensile strength and elongation of NBR.

*NBR compound (phr); Nipol-1042 (100), SRF black (40), St (1), ZnO(5), TMTM (0.5), AHF resin (80), TTN (ver.), $\mathrm{S}(1.5)$

Press condition $; 190^{\circ} \mathrm{C} \mathrm{CX} 30 \mathrm{~min}$

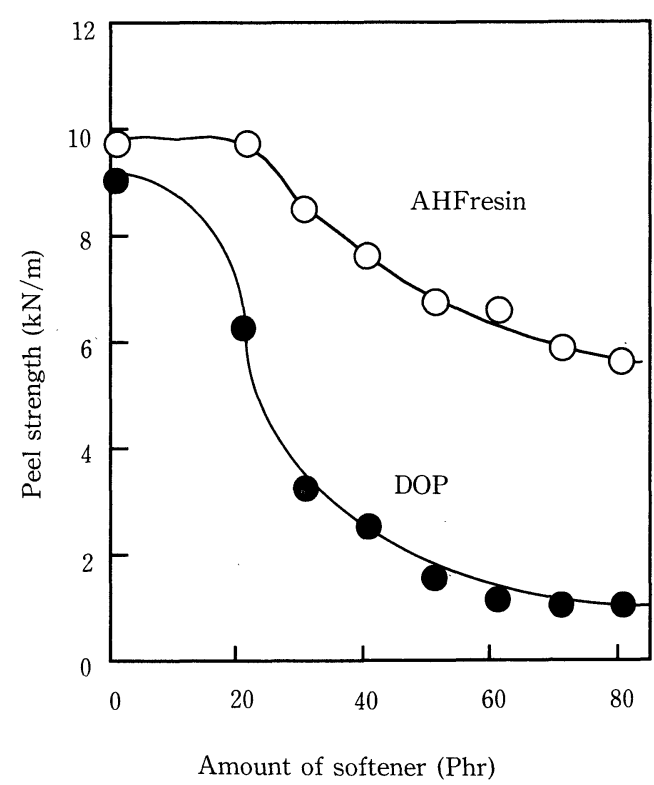

Fig. 6 Effect of the amount of softener on the peel strength of NBR-nickel plated adherends.

*NBR compound (phr) ; Nipol-1042(100), SRF black (40), $\mathrm{St}(1), \mathrm{ZnO}(5)$, AHF resin or DOP(ver.), TTN (1. 5), $\operatorname{TMTM}(0.5)$

Press condition $; 190^{\circ} \mathrm{C}$ for $30 \mathrm{~min}$ 


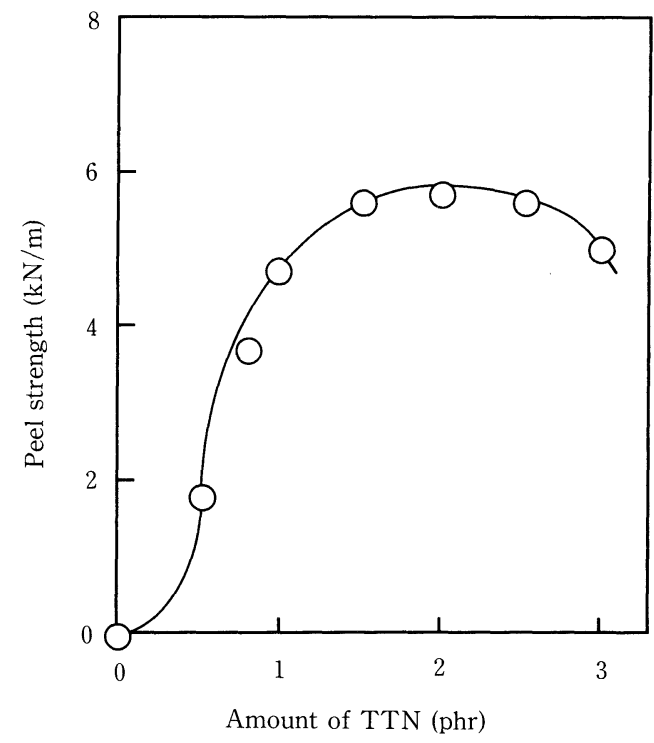

Fig. 7 Effect of the amount of TTN on the peel strength of NBR-nickel plated iron adherends.

*NBR compound (phr) ; Nipol-1042(100), SRF black (40), St (1), ZnO(5), TMTM (0.5), AHF resin(80), S(1. 5), TTN (ver.)

Press condition; $190^{\circ} \mathrm{C}$ for $30 \mathrm{~min}$

が加硫促進剂と反応しジスルフィド結合を形成す るためと考えられる。この結果より， AHF 樹脂 配合 NBR はニッケルめっきとのバインダーとな るTTNが $1 \mathrm{phr}$ 配合されてもゴム物性には影 響しないが, $2 \mathrm{phr}$ 以上配合すると $\mathrm{T}_{\mathrm{B}}$ 度が低下 することが明らかとなった。

\section{2 直接加硫接着}

振動減衰性のある軟化剂配合 NBR とニッケル めっきとの直接加硫接着を検討した. Fig. 6 は二 ッケルめっきと軟化剂配合 NBRの直接加硫接着 のはく離強度に及ぼす軟化剂配合量の影響を示し ている. $\mathrm{AHF}$ 樹脂の配合量が増加するとともに 接着強度は低下しているが, はく離試験後のゴム の破壊状態はすべてゴム破断となった。接着強度 の低下は $\mathrm{AHF}$ 樹脂配合によるゴム自体の $\mathrm{T}_{\mathrm{B}}$ の 低下によるものと考えられる。一方, DOP 配合 $\mathrm{NBR}$ では AHF 樹脂配合 NBR と同様に配合量 の増加とともにはく離強度は低下し，20 phr 付 近まではゴム破断であったが，それ以上配合する とはく離強度は $\mathrm{AHF}$ 樹脂配合 NBR より更に低 下し界面はく離となった。このことから， AHF

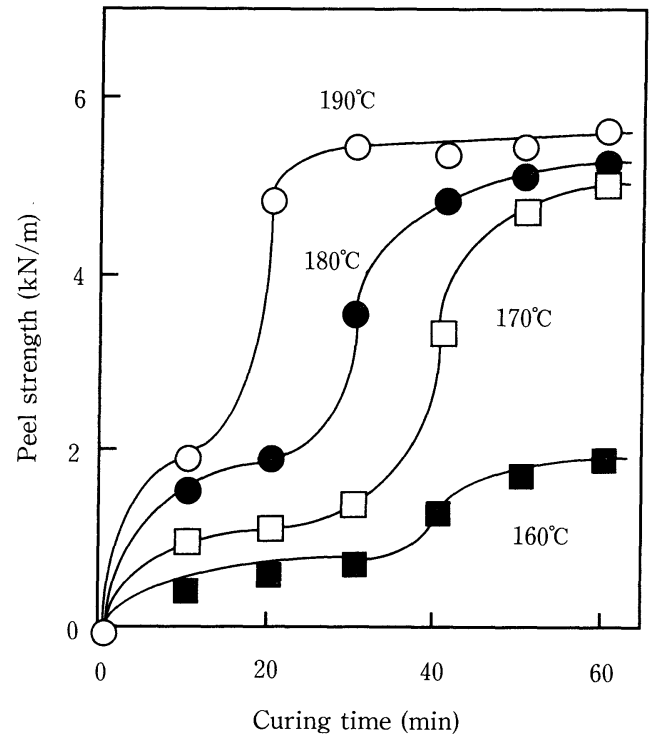

Fig. 8 Effect of curing times and curing temperatures on the peel strength of NBR-nickel plated iron adherends.

*NBR compound (phr) ; Nipol-1042(100), SRF black (40), St (1), ZnO(5), TMTM (0.5)

AHF resin (80), S(1.5), TTN (1.5)

樹脂は直接加硫接着に良好な軟化剂と考えられ る. Fig. 7 は接着力に及ぼす TTN 配合量の影響 を示している。バインダーとなる TTN を軟化鼡 配合 NBR に配合しないと全く接着しなかった。

$\mathrm{AHF}$ 樹脂配合 NBR の場合には，TTN 量の増 加に伴い接着物のはく離強度は増加し $1.5 \mathrm{phr}$ で 最大值を示し, その後減少する. TTN 量が 1 〜 $2 \mathrm{phr}$ の接着物は, はく離試験においてゴム 破断するほど強固な接着力を示した。 TTN 量の 増加とともにはく離強度が増加するのは, TTN がニッケルと NBR を結合するバインダーとして 作用し一次結合量が増えるためであり，はく離強 度が最大值のところでは，バインダーとの結合量 が最適值に達していると考えられる．更に添加量 を増加させると接着力が低下するのは, バインダ 一との結合量が増加し過ぎて, 接着界面付近でゴ ムの応力集中が起こりはく離強度が減少すること と, TTN と加硫剂又は加硫促進剂の比が崩れ て，TTN とゴムの反応あるいは TTN とニッケ ルめっきとの反応が起こりにくくなり，はく離強 度が低下したと考えられる．Fig. 8 はニッケルめ つきと軟化剂配合 NBR の直接加硫接着のはく離 


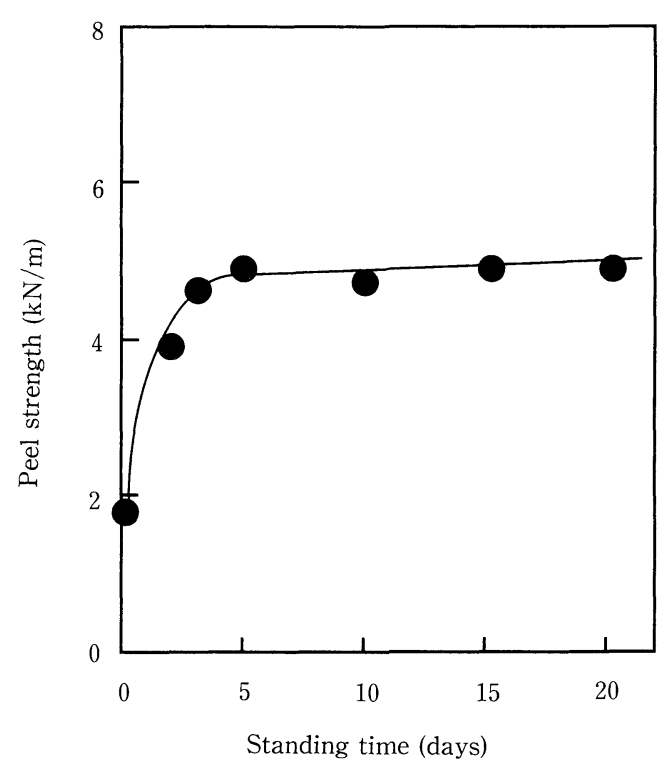

Fig. 9 Effect of the standing time of nickel plating on the peel strength of NBR-nickel plated adherends.

${ }^{*}$ NBR compound (phr) ; Nipol-1042(100), SRF black (40), St (1), $\mathrm{ZnO}(5)$, AHF resin(80), S(1.5), TTN (1.5)

Press condition; $190^{\circ} \mathrm{C}$ for $30 \mathrm{~min}$

強度に及ぼす加硫温度と加硫時間の影響を示して いる. 加硫温度が高温ほど短時間で接着強度が増 大している。 $190^{\circ} \mathrm{C} の$ 場合，加硫時間 $20 \mathrm{~min}$. 以 上でゴム破断するほどの強い接着力を示した．加 硫温度が増大するほどまた加硫時間が長時間ほど 接着強度が増大するのは, 後述するバインダーと なる TTN がニッケル界面に局在化し, 接着層と なる補強層が増大したためと考えられる。Fig. 9 はニッケルめっき後の放置時間の影響を示してい る. めっき直後および一日放置後では光沢界面は く離となった. 光沢界面はく離とは, ゴム界面に 約 200 500 ̊のニッケルが転写しニッケルめっ き層間ではく離した状態である。これはニッケル とトリアジントリチオールの反応性が強いため, 内部のニッケルと表層部のニッケル酸化被膜層が 傾斜構造を形成せず安定した表面を形成していな いためと考えられる.すなわち，無電解ニッケル めっき後経時とともにニッケル表面にある厚さの ニッケル酸化被膜層が成長し, 更に酸化被膜層と 内部のニッケルが安定するには, 室温では 48 時 間以上放置する必要があると考えられる。したが

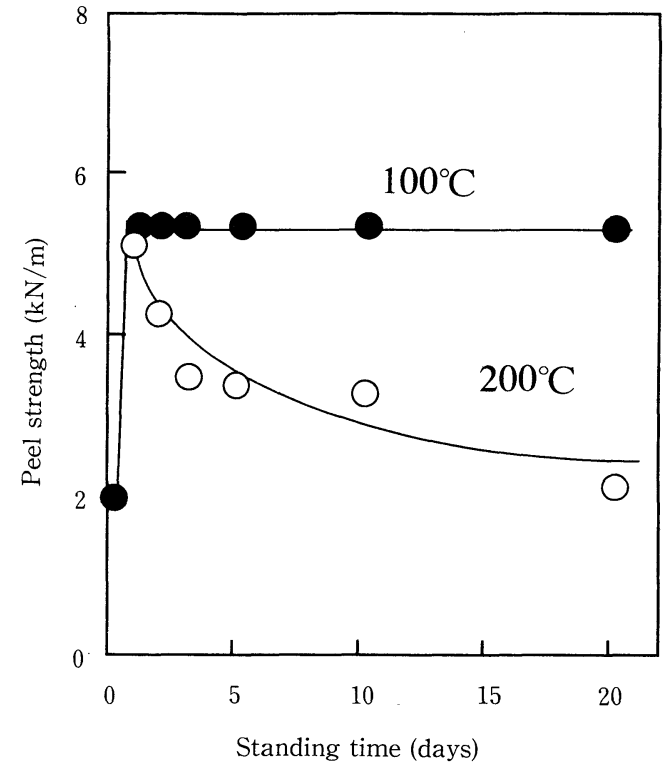

Fig. 10 Effect of the standing time and temperature of nickel plating on the peel strength of NBRnickel plated adherends.

*NBR compound (phr) ; Nipol-1042(100), SRF black (40), St (1), $\mathrm{ZnO}(5)$, AHF resin(80), S(1.5), TTN (1.5) Press condition; $190^{\circ} \mathrm{C}$ for $30 \mathrm{~min}$

Standing temperature of nickel plated $; 100^{\circ} \mathrm{C}, 200^{\circ} \mathrm{C}$

って，2 日以上放置し安定な酸化被膜を形成した ニッケルめっき板ではゴム破断となった．次に加 熱によりニッケル酸化被膜の厚さを変化させた場 合の影響を検討した. Fig.10はめっき直後に二

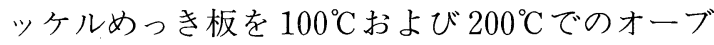

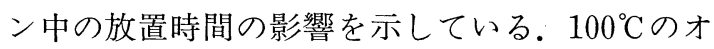
一ブン中に放置した場合, $30 \mathrm{~min}$. 以上でゴム破 断となり，20 時間放置しても $30 \mathrm{~min}$. と同様のゴ 厶破断となった。 $200^{\circ} \mathrm{C}$ の場合は $30 \mathrm{~min}$. で最大 のはく離強度を示し, 放置時間の増加とともには く離強度は減少し界面はく離となる結果となっ

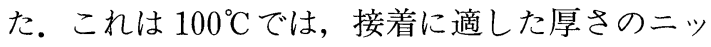

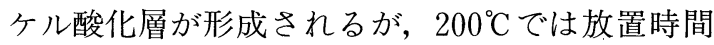
の増加とともにニッケル酸化層が厚く形成したた め TTN との反応点が減少し, はく離強度が低下

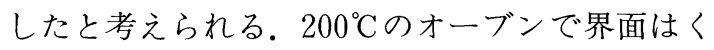
離を示したニッケルめっき板でも, 濃塩酸に 1 min.間浸せきすることによって表面の酸化層が除 去され，ゴム破断を起こすほどに接着力が回復し た. したがって，ニッケル酸化被膜層が直接加硫 

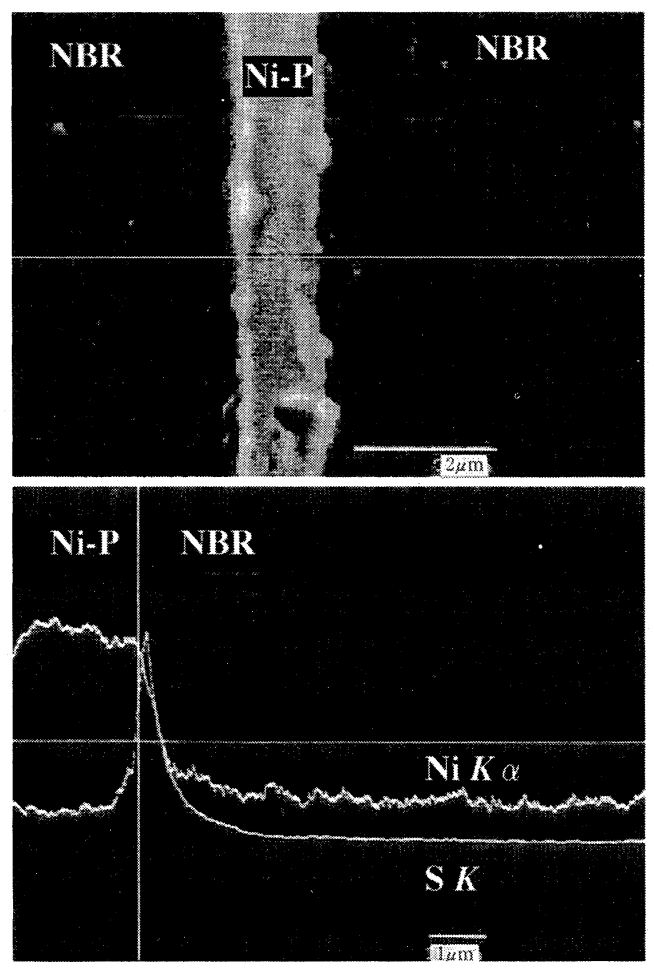

Fig. 11 SEM of NBR-nickel plated adherends interface and analysis by EDS of NBR-nickel plated adherends interface; NBR-nickel plated adherends broken in liquid nitrogen.

*NBR compound (phr) ; Nipol-1042(100), SRF black (40), St (1), ZnO (5), AHF resin (80), S (1.5), TTN (1.5) Press condition; $190^{\circ} \mathrm{C}$ for $30 \mathrm{~min}$

接着には影響を示すことが明らかとなった。

\section{3 接着界面の分析}

接着界面におけるニッケルとバインダーとして の TTN の反応を確認するために，接着界面を EDS で元素分析し検討した. Fig.11 は AHF 樹 脂配合 $\mathrm{NBR} /$ ニッケルめっき箔/AHF 樹脂配合 NBR サンドイッチ接着物を, 液体窒素で凍結破 壊した断面の SEM 写真(倍率 1,000 ) および S $(K)$ と $\mathrm{Ni}(K \alpha)$ の線分析(倍率 10,000$)$ の結果を 示している. SEM 写真より接着界面は液体窒素 で凍結破壊しても，はく離せず強固な接着性を示 していることが明らかである. 元素分析結果よ ク，ニッケルと NBRの界面付近でTTNによる と考えられる硫黄濃度が高くなり，加硫接着反応 によってTTN がニッケル界面に拡散しているこ

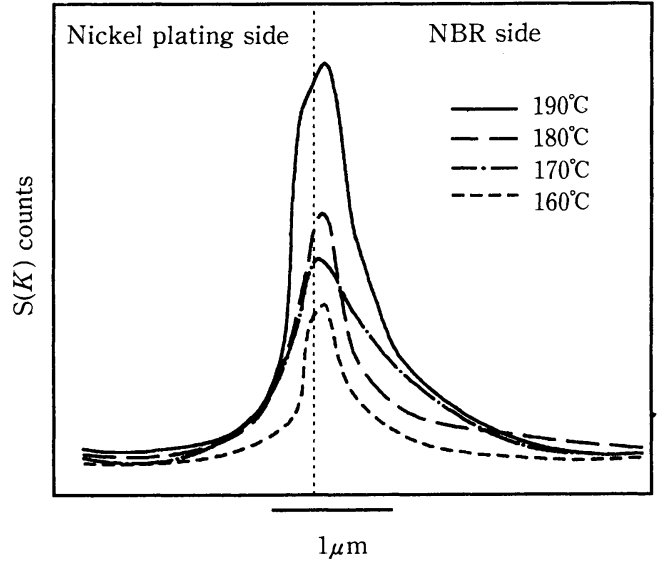

Fig. 12 Effect of the strength of $\mathrm{S}(K)$ on the curing temperature of NBR-nickel plated iron adherends.

*NBR compound (phr) ; Nipol-1042(100), SRF black (40), St (1), $\mathrm{ZnO}(5), \mathrm{AHF}$ resin (80), S (1.5), TTN (1.5) Press condition ; $30 \mathrm{~min}$

とがわかる．また，断定はできないがニッケルも ゴム側に拡散していると考えられる，界面はく離 を起こすような TTN 未配合の AHF 樹脂配合 NBR 接着物においては，このようなニッケル界 面付近で硫黄濃度が高くなる結果は全く確認でき なかった。この結果よりニッケルと NBRの界面 にはある厚さの接着界面層を形成し, 接着層は二 ッケルと硫黄との反応層すなわち接着補強層であ ク，ここでは TTN による NBRの加硫密度が高 く，堅い組織となっていると考えられる．Fig.12 は接着界面での $\mathrm{S}(K)$ の線分析を加硫温度を変化 させて測定した結果である。加硫温度の増大とと もに S $(K)$ の界面での相対強度は増大し, ニッケ ル界面への TTN の拡散も増大し, $190^{\circ} \mathrm{C}$ 加硫 温度では接着界面層が約 $1 \mu \mathrm{m}$ も形成されてい ることが観察される。加硫温度を $160^{\circ} \mathrm{C}$ から $190^{\circ} \mathrm{C}$ へと高温で加硫するにともない $\mathrm{S}(K)$ が増 加し，すなわち TTN が接着に関与していること が明らかである．これらの結果より，加硫温度の 増加とともにバインダーとなる TTN がニッケル 界面により多く局在化し, 接着性を安定化する接 着補強層を形成するものと考之られる. 以上のこ とから Fig.13のような機構で TTN が NBRの 加硫と同時にニッケルと界面でバインダーとして 作用し一次結合を形成していると考えられる. 


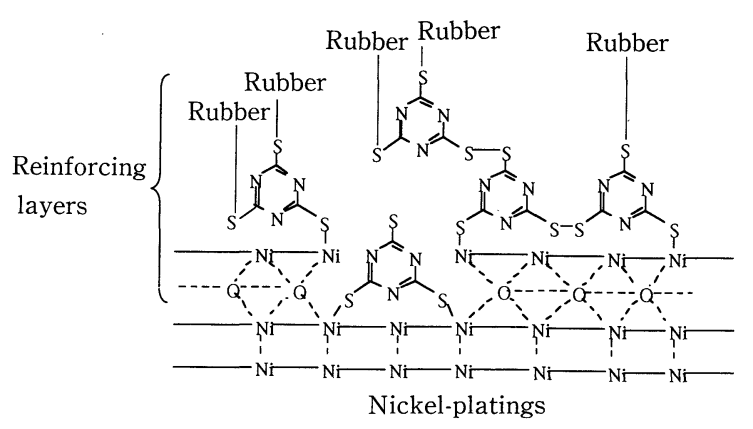

Fig. 13 The structure of interface between nickel platings/1, 3, 5-triazine-2,4,6-trithiols/NBR.

\section{4. 結}

\section{論}

TTN 配合系の NBR に軟化剂として AHF 樹 脂または DOP を配合した場合の NBRの物性と ニッケルめっきとの直接加硫接着について検討し た結果，以下のことが明らかとなった。

1） TTN を配合すると誘導期が短縮され加硫促 進剂として作用した。 $40 \mathrm{phr}$ まで軟化剂量を増 加させた場合, $\mathrm{AHF}$ 樹脂配合 NBR では， $\mathrm{T}_{\mathrm{B}}$ は $7.5 \mathrm{MPa}$ と一定の值を示し, $\mathrm{E}_{\mathrm{B}}$ は配合量の増加 とともに減少する傾向にあった。

2 ) ニッケルめっきとの直接加硫接着は, 軟化剂 $\mathrm{AHF}$ 樹脂を $80 \mathrm{phr}$ 配合しても凝集破壊となる接 着物が得られた。 また加硫温度が高温ほど短時間 で接着強度が増大した。
3) X線マイクロアナライザーで接着界面を分析 した結果より，ニッケルと NBRの界面付近で TTN によると考えられる硫黄濃度が高くなり, 加硫接着反応によってトリアジントリチオールが ニッケル界面に拡散していることがわかる。すな わち加硫温度の増加とともにバインダーとなるト リアジントリチオールが接着界面により多く局在 化し, 接着層すなわち接着補強層を形成し安定化 するものと考えられる.

\section{引 用 文 献}

1 ) 先端材料応用事典編集委員会編：(侏産業調査会事典出 版センター, 395(1990)

2 ) 高分子学会編：ポリマーアロイ基礎と応用第 2 版, 東 京化学同人, 55 (1993)

3 ) 大山哲夫：日ゴム協誌，64，734(1991)

4 ）例えば日ゴム協誌特集号防振, 制振, 防音, 64, 61 157 (1991), 日ゴム協誌特集号防振, 制振, 防音, 64，279３35(1991)，日ゴム協誌特集号防振，制振， 防音, 64, 710 798 (1991)

5 ）森邦夫，平原英俊，佐々木八重子：日ゴム協誌，65, 181(1992)

6 ) 平原英俊, 森邦夫, 大石好行：日ゴム協誌, 66, $552(1993)$

7 ) 森邦夫, 高橋進, 門口悌一郎：日ゴム協誌，63, $90(1990)$

8 ) 舞田雅広, 水口建治, 木村雅俊, 児玉総治, 森邦夫 : 日ゴム協誌, 66, 488(1993)

9 ) 森邦夫, 高橋治彦, 平原英俊, 佐々木八重子:日ゴム 協誌, 65, 171(1992) 